\title{
Getting to the root of the problem
}

\author{
Alan M. Speir, MD \\ From the Inova Heart and Vascular Institute, Falls Church, Va \\ Disclosures: Author has nothing to disclose with regard to commercial support. \\ Received for publication Feb 7, 2018; accepted for publication Feb 11, 2018; available ahead of print March 24, \\ 2018. \\ Address for reprints: Alan M. Speir, MD, Inova Heart and Vascular Institute, 3300 Gallows Rd, Falls Church, VA \\ 22042 (E-mail: alan.speir@inova.org). \\ J Thorac Cardiovasc Surg 2018;156:96-7 \\ $0022-5223 / \$ 36.00$ \\ Copyright $\subset 2018$ by The American Association for Thoracic Surgery \\ https://doi.org/10.1016/j.jtcvs.2018.02.019
}

In this month's issue of the Journal, Urbanski and colleagues ${ }^{1}$ present their results of reoperative complete root replacement in patients with relevant root pathology after previous aortic valve or complete root replacement. In these patient groups, endocarditis was present in $27.7 \%$ of those with previous aortic valve replacements and $75 \%$ of those with previous Bentall procedures. The stated aim of the article was to demonstrate the utility of a "self-assembled conduit" in patients with a destroyed aortic annulus where no surgical alternative to complete aortic root replacement was deemed appropriate. In this single-center analysis spanning 14 years, a series of 560 patients was evaluated, with a mean follow-up of $63 \pm 47$ months. The follow-up results with no new or recurrent endocarditis is impressive. There were 6 in-hospital deaths, with 30 deaths reported beyond the 30-day postoperative period. Survivals at 1, 5, and 10 years were quite good at $84.8 \% \pm 3.4 \%$, $75.7 \% \pm 4.3 \%$, and $57.1 \% \pm 6.5 \%$, respectively.

For many years, the consensus within the cardiac surgery community was to use biologic material rather than prosthetic devices for surgical repair in the presence of infection..$^{2-6}$ In the early part of this century, however, numerous reports of favorable results of endocarditis treatment with prosthetic materials appeared in the literature, challenging that consensus. ${ }^{7-9}$ This publication of Urbanski and colleagues ${ }^{1}$ is another cardiac surgical series that demonstrates excellent outcomes in the surgical treatment of prosthetic endocarditis with prosthetic valves and material. It underscores the central tenet in the surgical treatment of this challenging clinical condition that extensive débridement of all infected tissue is more important than the type of prosthesis used for valvular replacement. $^{7,10,11}$

This surgical alternative for the treatment of annular destruction from endocarditis could not be timelier, and our opportunity to use this surgical option may be increasing because of the growing national opioid crisis. It has been suggested that the policies designed to reduce inappropriate prescriptions of opioid medications are now linked to the increased rates of parenteral heroin use and

\section{References}

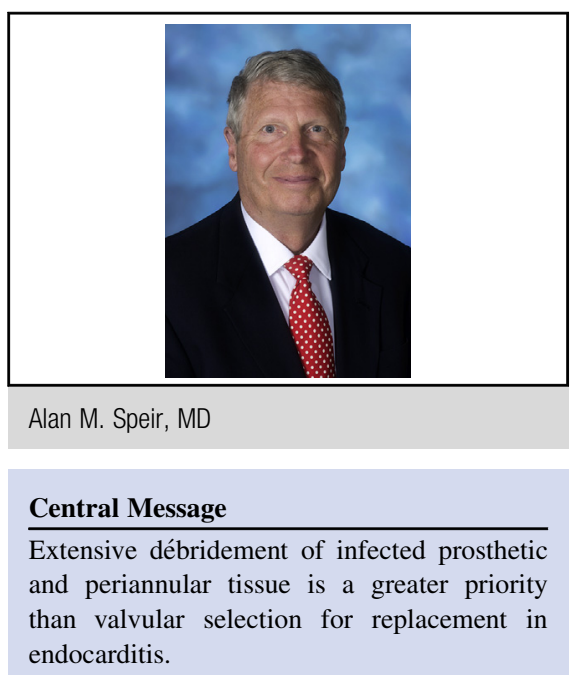

See Article page 89.

death. ${ }^{9}$ According to the 2014 National Survey on Drug Use and Health, 914,000 people reported heroin use in 2014 , a $145 \%$ increase since $2007,,^{12}$ and mortality from heroin overdose has more than quintupled, from 1842 deaths in 2000 to 10,574 deaths in $2014 .{ }^{13}$ This epidemic cannot help but have a profound impact on our specialty because of the anticipated increase in the rates of endocarditis from parenteral drug abuse, which may well result in urgent or emergency surgical treatment. I expect not only that cardiac surgeons will have increased opportunities to address these challenges surgically in the future, but that they may also be motivated to alter their prescribing practices for postoperative pain, which may be contributing to the root cause of this problem to begin with.

1. Urbanski PP, Lakew F, Dinstak W, Heinz N, Zacher M, Irimie V, et al. Bentall procedure after previous aortic valve or complete root replacement: usefulness of self-assembled aortic valve conduit. J Thorac Cardiovasc Surg. 2018;156:89-95.

2. Vogt PR, Turina MI. Management of infected aortic grafts: development of less invasive surgery using cryopreserved homografts. Ann Thorac Surg. 1999;67: 1986-9; discussion 1997-8.

3. Niwaya K, Knott-Craig CJ, Santangelo K, Lane MM, Chandrasekaran K, Elkins RC. Advantage of autograft and homograft valve replacement for complex aortic valve endocarditis. Ann Thorac Surg. 1999;67:1603-8.

4. Koskas F, Goëau-Brissonnière O, Nicolas MH, Bacourt F, Kieffer E. Arteries from human beings are less infectible by Staphylococcus aureus than polytetrafluorethylene in an aortic dog model. J Vasc Surg. 1996;23:472-6.

5. Prat A, Grandmougin D, Decoene C, Godart FR, Saez de Ibarra JI, Savoye C, et al. Aortic root replacement with a pulmonary autograft in young adults: medium-term results in 70 patients. Ann Thorac Surg. 1998;66:148-52.

6. Hagl C, Galla JD, Lansman SL, Fink D, Bodian CA, Spielvogel D, et al. Replacing the ascending aorta and aortic valve for acute prosthetic valve endocarditis: is using prosthetic material contraindicated? Ann Thorac Surg. 2002;74:S1781-5; discussion S1792-9. 
7. Bauernschmitt R, Jakob HG, Vahl CF, Lange R, Hagl S. Operation for infective endocarditis: results after implantation of mechanical valves. Ann Thorac Surg. 1998;65:359-64.

8. Aagaard J, Andersen PV. Acute endocarditis treated with radical debridement and implantation of mechanical or stented bioprosthetic devices. Ann Thorac Surg. 2001;71:100-3; discussion 104.

9. Cicero TJ, Ellis MS, Surratt HL. Effect of abuse-deterrent formulation of OxyContin. N Engl J Med. 2012;367:187-9.

10. Lytle BW, Sabik JF, Blackstone EH, Svensson LG, Pettersson GB, Cosgrove DM III. Reoperative cryopreserved root and ascending aorta replacement for acute aortic prosthetic valve endocarditis. Ann Thorac Surg. 2002;74: S1754-7; discussion S1792-9.
11. d'Udekem Y, David TE, Feindel CM, Armstrong S, Sun Z. Long-term results of operation for paravalvular abscess. Ann Thorac Surg. 1996;62:48-53.

12. Center for Behavioral Health Statistics and Quality. 2014 National Survey on Drug Use and Health: detailed tables. Available at: https://www samhsa.gov/data/sites/default/files/NSDUH-DetTabs2014/NSDUH-DetTabs2014. pdf. Accessed February 7, 2018.

13. Centers for Disease Control and Prevention, Wide-ranging Online Data for Epidemiologic Research (WONDER). Number and age-adjusted rates of drug-poisoning deaths involving opioid analgesics and heroin: United States, 1999-2014. Available at: http://www.cdc.gov/nchs/data/health policy/AADR_drug_poisoning_involving_OA_Heroin_US_2000-2014.pdf. Accessed February 7, 2018 